\title{
Silencing Cities
}

\author{
David Sharp
}

Today a wholly silent city would be a dead one, yet we know that exposure to too many decibels is unhealthy. Even in ancient Rome, the din of chariots was regulated, but where is the line to be drawn in what the World Health Organization defines as community or nonindustrial noise?

In the United Kingdom, the government has decided to look again at current legislation, which has proved a dismal failure. We used to have a separate law on noise abatement, but since 1974, noise has been covered by the Control of Pollution Act. This gives powers to local authorities, but only if they adopt the whole package. Since that involves monitoring units and is expensive, few councils have bothered. Complaining to the town hall about an all-night party that disturbs children and shift workers in neighboring apartments is often a waste of time.

Noise is difficult to regulate, not least because of the subjectivity of its perception. To me, a heavy metal pop concert is a din, while a Wagnerian soprano in full voice is not, and cell phones on a train irritate even if they do not break decibel guidelines. Also, the decibel, as the logarithm of a ratio, is not easy to handle or explain.

Accompanying recognition of the failure of current legislation in the United Kingdom are evidence from research and the successful use of European human rights legislation. A study ${ }^{1}$ from Sheffield's Hallam University last year suggested that British cities are getting noisier. Raymond Heng's group ${ }^{1}$ has over 10 years recorded a doubling in acoustic energy and a 10-fold increase in some places. Our inner cities are seeing a regeneration. A decade and more ago, there was no one to be disturbed at night. Then, the West London Schools Study ${ }^{2}$ revealed some impact of aircraft noise on the cognitive performance of children.

Sometimes it takes a legal case to make a real impact, and the European Court of Human Rights is proving a nightmare for Britain's governors, local and national. A normal night's sleep is a human right, so ruled the court on October 2, 2001, in a case brought by eight Londoners living under Heathrow Airport's flight path. ${ }^{3}$ That verdict has not stopped the proposed fifth terminal at that airport, although its supporters have been forced into the unconvincing arithmetic of claiming that a huge increase in passengers will not be matched by much growth in flights. The court's decision is worrying central London's Westminster City Council. That council receives 18,000 complaints about noise in a year ${ }^{4}$ and now fears that residents will be looking to the European courts for a remedy against nights disturbed by the many pubs and clubs in districts such as Soho.

Urban noise is not limited to the Western world. Indian cities such as Mumbai (Bombay) have the worst noise pollution in the world. I see that April 24, 2002, was set aside as International Noise Awareness Day-a time for quiet protest, presumably. 


\section{REFERENCES}

1. School of Engineering, Sheffield Hallam University. News: research reveals major city centre noise headache. Available at: http://www.shu.ac.uk/schools/eng/industry/newsnoise. html. Accessed January 2, 2002.

2. Haines MM, Stansfeld SA, Brentnall S, et al. The West London Schools Study: the effects of chronic aircraft noise exposure on child health. Psychol Med. 2001;31:1385-1396.

3. Hatton and others $v$ United Kingdom, application no 36022/97. Strasbourg: European Court of Human Rights, 2001.

4. Westminster City Council media release. October 4, 2001: ref 321. Available at: http:// www.westminster.gov.uk/news/2001/pr_noise.cfm. Accessed January 3, 2002. 